\title{
Corrigendum: Numerical Simulation of the Dynamic Response of Ballasted Track Overlying a Tire-Reinforced Capping Layer
}

\author{
Qideng Sun ${ }^{1 * t}$, Buddhima Indraratna ${ }^{2 \neq}$ and Jim Grant $^{3}$ \\ ${ }^{1}$ Coffey Services Australia Pty Ltd, Chatswood, NSW, Australia, ${ }^{2}$ Transport Research Centre, University of Technology, \\ Sydney, NSW, Australia, ${ }^{3}$ Ecoflex International Pty Ltd, Avoca Beach, NSW, Australia
}

Keywords: track dynamics, finite-element modeling, vibration, reinforced soils, capping layer, scrap tire

\section{OPEN ACCESS}

Approved by:

Frontiers Editorial Office

Frontiers Media SA, Switzerland

*Correspondence:

Qideng Sun

Peter.Sun@Coffey.com

${ }^{\dagger}$ Formerly worked as an Associate Research Fellow at University of

Wollongong, Australia

${ }^{\ddagger}$ Formerly worked at ARC Industrial Transformation Training Centre,

ITTC-Rail, c/o University of

Wollongong, Wollongong, NSW,

Australia

Specialty section

This article was submitted to Transportation and Transit Systems, a section of the journal

Frontiers in Built Environment

Received: 10 June 2020

Accepted: 22 June 2020

Published: 07 August 2020

Citation:

Sun Q, Indraratna B and Grant J

(2020) Corrigendum: Numerical Simulation of the Dynamic Response

of Ballasted Track Overlying a

Tire-Reinforced Capping Layer.

Front. Built Environ. 6:115.

doi: 10.3389/fbuil.2020.00115

\section{A Corrigendum on}

Numerical Simulation of the Dynamic Response of Ballasted Track Overlying a Tire-Reinforced Capping Layer

by Sun, Q. (2020). Front. Built Environ. 6:6. doi: 10.3389/fbuil.2020.00006

Buddhima Indraratna and Jim Grant were inadvertently omitted as authors in the published article. The corrected Author Contributions Statement and Affiliations appear below:

The following affiliation for the 2nd author Buddhima Indraratna was added: "Transport Research Centre, University of Technology, Sydney, NSW, Australia. Formerly worked at ARC Industrial Transformation Training Centre, ITTC-Rail, c/o University of Wollongong, Wollongong, NSW, Australia."

The following affiliation for the 3rd author Jim Grant were added as "Ecoflex International Pty Ltd, Avoca Beach, NSW, Australia."

The corrected Author Contributions Statement appears below:

BI had provided very critical and constructive review comments at different stages of this work, and was the project leader of this sponsored industry-based research. JG had participated in discussions and provided inspirational comments at various stages of this work, and his company EcoFlex has already put to practice the rubber-tyer assembly concept in numerous Australian road projects. QS approved the article for publication.

Furthermore, in the original article, there was an error in the acknowledgments section. Funding and an acknowledgments of contributions of additional researchers have been added. The following correction has been made:

"The first author formerly worked as an Associate Research Fellow at University of Wollongong. The authors acknowledge the financial assistance provided by the NSW Environmental Trust, TSA, Ecoflex International Pty Ltd and University of Wollongong. The original concept of tyer assembly for roads was an invention by EcoFlex. The authors are thankful to Dr. Trung Ngo and Dr. Ana Heitor for their valuable review comments to this paper. Assistance of A/Prof. Cholachat Rujikiatkamjorn at various times during this project is also appreciated. Contributions from Dr. Mahdi Biabani through similar conceptual research based on geocell reinforced tracks under the guidance of Distinguished Professor 
Indraratna supported by EcoFlex also inspired this particular study."

The Conflict of Interest statement has also been updated to reflect the addition affiliation of Ecoflex International Pty Ltd. The new Conflict of Interest statement reads as follows: "QS was employed by the company Coffey Services Australia Pty Ltd. JG was employed by the company Ecoflex International Pty Ltd.

The remaining author declares that the research was conducted in the absence of any commercial or financial relationships that could be construed as a potential conflict of interest."
The authors apologize for these errors and state that this does not change the scientific conclusions of the article in any way. The original article has been updated.

Copyright (c) 2020 Sun, Indraratna and Grant. This is an open-access article distributed under the terms of the Creative Commons Attribution License (CC BY). The use, distribution or reproduction in other forums is permitted, provided the original author(s) and the copyright owner(s) are credited and that the original publication in this journal is cited, in accordance with accepted academic practice. No use, distribution or reproduction is permitted which does not comply with these terms. 